\title{
Long Term Mortality in Hospitalized Chronic Obstructive Pulmonary Disease Exacerbation: A Comparison of Multiple Indices
}

\author{
Hastanede Kronik Obstruktif Akciğer Hastalı̆̆ı Ataklarında Uzun Dönem Mortalite: Çoklu İndekslerin \\ Karşılaştırılması
}

${ }^{1}$ Gulcin Sari, ${ }^{1}$ Hatice Kilic, ${ }^{3}$ Senay Yilmaz, ${ }^{4}$ Ayse Baha, ${ }^{5}$ Asiye Ugras Dikmen, ${ }^{1}$ Nurdan Kokturk

${ }^{1}$ Department of Pulmonology, Gazi University School of Medicine, Ankara, Turkey

${ }^{2}$ Department of Pulmonology, Ankara Yildirim Beyazit University School of Medicine, Ankara, Turkey

${ }^{3}$ Department of Pulmonology, Eskisehir Osmangazi University School of Medicine, Eskisehir, Turkey

${ }^{4}$ Department of Pulmonology, Near East University Faculty of Medicine, Cyprus

${ }^{5}$ Department of Public Health, Gazi University School of Medicine,

Ankara, Turkey

${ }^{6}$ Department of Pulmonology, Gazi University School of Medicine,

Ankara, Turkey

\section{Correspondence:}

Senay YILMAZ

Department of Pulmonology, Eskisehir Osmangazi University School of Medicine, Eskişehir, Turkey

e-mail:

senayyilmazesogugmail.com

\section{Abstract}

The aim of this study is to identify the factors affecting mortality in patients with chronic obstructive pulmonary disease (COPD) hospitalized with exacerbation. A COPD cohort study was designed. Demographic data, the reason of mortality, Charlson co-morbidity index (CCI), COPD comorbidity index (COTE), age, dyspnea, airway obstruction (ADO) index, modified ADO index and dyspnea, airway obstruction, smoking, exacerbation (DOSE) index, and their relationship with mortality were investigated. One hundred and forty COPD patients hospitalized with exacerbation were included in the study. Eighty-seven (62.15\%) of the patients were alive and $53(37.85 \%)$ of them were deceased. The number of patients with CCI $\geq 7$ was none in living patients and $11(20.8 \%)$ in the deceased group $(\mathrm{p}<0.001)$. The percentage of treatment compliant patients during stable conditions was lower in the deceased group $(\mathrm{p}<0.001)$. ADO and COTE indices were significantly higher in the deceased group. There was no difference in modified ADO and DOSE scores between the groups. Multivariate analysis showed that lung cancer, CCI 7, hypoxemia $(\mathrm{PaO} 2<60$ $\mathrm{mmHg}$ ), and longer admission to the intensive care unit were independently associated with $3.4,4.4,2.1$, and 3.0 -fold mortality, respectively ( $\mathrm{p}<0.05)$. Additionally, COTE $\geq 4$ and noncompliance to regular COPD treatment were found to be associated with shorter survival in Kaplan Meier analysis $(\mathrm{p}<0.05)$. In conclusion, comorbidities and most notably lung cancer was associated with mortality in COPD. Also, high CCI and COTE index were risk factors for increased mortality.

Keywords: COPD, mortality, ADO, DOSE, COTE, CCI

Özet

Bu çalışmada amaç kronik obstrüktif akciğer hastalığı (KOAH) alevlenmesi ile hastaneye yatırılan olan hastalarda mortaliteyi etkileyen faktörleri belirlemektir. Bir KOAH kohort çalıșması tasarlanmıștır. Demografik veriler, mortalite nedeni, Charlson komorbidite indeksi (CCI), KOAH komorbidite indeksi (COTE), yaş, dispne, hava yolu tıkanma (ADO) indeksi, modifiye ADO indeksi ve dispne, hava yolu tıkanması, sigara, alevlenme (DOSE) indeksi ve bunların mortalite ile ilișkisi araștırıldı. Calıșmaya KOAH alevlenmesi ile yatan $140 \mathrm{KOAH}$ hastası dahil edildi. Hastaların 87’si (\%62.15) hayatta iken 53’ü (\%37.85) ölmüştü. Yaşayan hastalarda CCI $\geq 7$ olan hasta yokken, ölen grupta $11(\% 20.8)$ kişide CCI $\geq 7$ idi $(\mathrm{p}<0.001)$. Stabil durumda tedaviye uyumlu hasta yüzdesi ölen grupta daha düșüktü $(p<0.001)$. Değiștirilmiș ADO indeks yüzdesi ölen grupta daha düșüktü $(p<0.001)$. Ölen grupta ADO ve COTE indeksleri anlamlı olarak daha yüksekti. Gruplar arasında modifiye ADO ve DOSE skorlarında fark yoktu. Çok değişkenli analiz, akciğer kanseri, $\mathrm{CCI} \geq 7$, hipoksemi $(\mathrm{PaO} 2<60 \mathrm{mmHg})$ ve yoğun bakım ünitesine daha uzun başvuru almaşının sırasıyla 3.4, 4.4, 2.1 ve 3.0 kat mortalite ile bağımsız olarak ilişkili olduğunu gösterdi $(\mathrm{p}<0.05)$. Ek olarak, Kaplan Meier analizinde COTE $\geq 4$ ve düzenli KOAH tedavisine uyumsuzluğun daha kısa sağkalım ile ilişkili olduğu bulunmuştur $(\mathrm{p}<0.05)$. Sonuç olarak, komorbiditeler ve en belirgin olarak akciğer kanseri, KOAH'da mortalite ile ilişkkili bulunmuştur. Aynı zamanda yüksek CCI ve COTE indeksleri de mortalite ile ilişkilidir.

Anahtar Kelimeler: KOAH, mortalite, ADO, DOSE, COTE, CCI

Received 03.06.2021 Accepted 26.07.2021 Online published 28.07.2021 


\section{Introduction}

Chronic obstructive pulmonary disease (COPD) causes 3.2 million deaths worldwide comprising the third leading cause of death in 2017 and becomes in 2030 the third leading cause of death worldwide $(1,2)$. Systemic manifestations correlate with increased risk of mortality in COPD and may be considered surrogates of disease severity. There are several clinical surrogates such as airflow obstruction, age, dyspnea, malnutrition, exercise capacity, hypoxemia, lung hyperinflation and exacerbations that have long been evaluated for mortality prediction (3-5). Comorbidities are known as the major contributors in morbidity and mortality in COPD (6). The most prevalent comorbidities include anxiety/depression, heart failure, ischemic heart disease, pulmonary hypertension, metabolic syndrome, diabetes, osteoporosis, and gastroesophageal reflux disease (7).

Charlson comorbidity index (CCI) was introduced for classifying comorbidities as a valid method of estimating risk of death from comorbid conditions (8). Recently, Divo et al. described comorbidities strongly correlated with mortality in COPD patients named as 'COPD comorbidity (COTE) index' to form 'comorbidome' in COPD (9).

In recent years, several composite indices have been introduced to establish a multidimensional risk assessment of mortality. BODE (Body mass index, Obstruction, Dyspnea, Exercise capacity), ADO (Age, Dyspnea, Obstruction), DOSE (Dyspnea, Obstruction, Smoking, Exacerbation), and the several variants including BODEX (Body mass index, Obstruction, Dyspnea, Severe exacerbation) and CODEX (Comorbidity, Obstruction, Dyspnea, Severe exacerbation) indices are known in the studies $(10,11)$. This study was aimed to define the clinical prognostic markers and indices of exacerbated COPD patients for short and long term mortality.

\section{Material and Methods}

\section{Subjects and Study Design}

This is a retrospective COPD cohort study. A total of 753 patients were screened who were hospitalized under the diagnosis of COPD at the Department of Pulmonary Disease in Gazi University, School of Medicine between January 2000 and May 2011. Information of the patients was obtained through the patients' records and the electronic database of the hospital. The complete information was obtained in 324 COPD patients out of 753 scanned patient files. The patients with incomplete record and who were suspected of asthma were excluded from the study. Death status could be achieved in 168 of 324 patients whose files were obtained. The relatives of the patients who died were asked about the date and reasons of death verbally. Death information confirmed from hospital registration system. Considering the death dates of the patients and the years of COPD diagnosis, their lifespan with the disease were determined. Of the patients whose survival information was obtained, 140 of them who were treated at hospital due to exacerbation were included in the study.

Demographic data of the patients on admission period when they were included in the study (index date), dyspnea levels, smoking history, prebronchodilator pulmonary function tests (PFTs), comorbidities, the medication for COPD and comorbidities, long-term oxygen treatment (LTOT), the use of noninvasive mechanical ventilator (NIMV) at home and the the use of nebulizer were recorded from hospital records.

The technical steps in the use of the inhaler device could not be obtained. The patients and/or their relatives who were contacted through telephone were asked whether they were using inhaler medicine, whether they complied with the recommended period and dose, and whether they skipped any dose. The patients who used LTOT and NIMV were also 
asked whether they complied with the recommended period and frequency.

The presence of comorbidities proven by patient's self-declaration or by medical records was obtained from the patients' reports and medical examination results. CCI and COTE were retrospectively calculated in the groups.

The number of exacerbations requiring antibiotic treatment and/or oral corticosteroid that they underwent the previous year, and the numbers of stays at hospital and intensive care unit for these reasons were recorded. The reasons for exacerbation at the patients' present hospitalization, arterial blood gas measured at room air at the moment of admission, the duration of hospital stay and the need for intubation and the intensive care unit admission were recorded. ADO, modified ADO, DOSE scorings were retrospectively calculated.

The effects of all the parameters on mortality and survival were assessed with the univariate, multivariate logistic regression model, Kaplan Meier and Cox regression model. The study was approved by the Gazi University School of Medicine, Institutional Review Board (Approval number: 248/2011).

\section{Diagnosis, Definitions and Evaluation Tools}

The diagnosis of COPD was established according to the Global Initiative for Obstructive Lung Disease (GOLD) Guideline in a stable condition (12). Accordingly, a forced expiratory volume in one second/forced vital capacity (FEV1/FVC) < 0.7 and a compatible medical history were required for the diagnosis (12).

PFTs were performed with Sensor Medics Vmax20 Spirometer in sitting position while wearing a noseclip. Three full inspiration and forced expiration maneuvers were performed according to the European Respiratory Society (ERS) Criteria. The recorded values were taken from the best of three forced expiratory measurements (13).
COPD exacerbation was defined as an increase of symptoms beyond the normal daily variability which need a treatment change. Exacerbations that need to be treated with oral corticosteroids and/or antibiotics were defined as moderate exacerbations. Two or more moderate exacerbations per year were defined as frequent exacerbation (14). Dyspnea was evaluated with modified Medical Research Council (mMRC) at the index admission (15). Infectious exacerbations were defined by Anthonisen's Criteria. According to this definition, the patient has to have at least one of the following three symptoms; increased dyspnea, increased sputum production and purulent sputum (14). Type I exacerbation (severe) is characterized by all of the three symptoms; Type II (moderate) is characterized by two of the three symptoms; Type III (mild) is characterized by only one of the three symptoms and at least one of symptoms related with upper airway infectious symptoms (14).

Lung conditions, such as pneumonia, pulmonary embolism, bronchiectasis and lung carcinoma, were defined by radiological findings and an appropriate clinical picture. Bronchiectasis was only recorded if there was a radiologically considerable amount of bronchiectatic lung area (16). CCI is an automatized method designed to determine for analytic purposes. In this method, the patients were classified in such a way as to take 1, 2, 3 and 6 points and the total score of the patients' combordities in this scale were categorized. With increased level of the comorbidity index, there were stepwise increases in the cumulative mortality attributable to comorbid disease (8).

COTE has been defined as a COPD specific index based on comorbidities that increase the risk of mortality. Similar to the CCI, a scale value points in the range of one to six point was assigned to each selected comorbidity in proportion to its Hazard Ratio (HR) (1-1.5=1, $>1.5-2=2$, and $>2=6$ points with an exception other cancers, which were assigned two points). A total score of 4 was chosen as a cut point as a predictor of increased mortality (9). 
'Compliant patients' were defined as the patients who used the recommended dose of medicine during the recommended period and they did not skip any dose. 'Noncompliant patients' were defined as the patients who skipped doses or never used any medicine. The use of LTOT 16 hours or more a day was described as 'regular usage' and the use of LTOT less than 16 hours a day or when pushed for it was described as 'irregular usage'. The use of NIMV at least two hours three times a day was defined as 'regular usage' and the use of NIMV less than two hours a day or when pushed for it was defined as 'irregular usage'.

ADO index is calculated with the parameters of age, dyspnea (mMRC) and airway obstruction (FEV1) (17). Accordingly, patients take scores between 0 and 2, depending on the level of obstruction; between 0 and 3, depending on the degree of dyspnea; and between 0 and 5, depending on the age. Modified ADO index is calculated with the parameters of age, (mMRC) and airway obstruction (FEV1), too. Total score varies between 0 to 11 . Unlike ADO index, however, patients take scores between 0 and 4 , depending on the level of obstruction and between 0 and 7 , depending on the age in modified ADO index. There is no difference between the scoring of both indices according to the degree of dyspnea. The total score varies between 0 and 14 . Though the exact limits are not determined for both indices, the increased score points to the worsened prognosis (18). DOSE scoring is a scoring system that helps predict the important results such as COPD patients' hospitalization, respiratory insufficiency and exacerbation. Dyspnea (mMRC) is calculated by using the parameters of airway obstruction (FEV1), smoking and the number of exacerbations (19). Patients take scores between 0 and 3, depending on the degree of dyspnea; between 0 and 2, depending on the level of obstruction; between 0 and 1, depending on smoking, and between 0 and 2, depending on the number of annual exacerbations. The patients whose scores are equal to and higher than 5 bear high risks in terms of hospitalization and respiratory insufficiency (19).

\section{Statistical Analysis}

Analysis of the data was made with SPSS for Windows 15 package programme. The risk factors had statistically significant effects on distinguishing the surviving group and the dying group was analyzed with Univariate Logistic Regression Analysis, Pearson's ChiSquare or Fisher's Chi-Square Test. Multivariate Logistic Regression Analysis was researched with Bacward LR Test. The rate of odds for each variable and 95\% confidence interval were calculated. Furthermore, the importance of the difference from the aspect of median values between the groups was analyzed with the Mann-Whitney U Test. Lifespan analysis was made with univariate Kaplan Meier, log-rank test. Lifespan analysis was made with the multivariate Cox regression analysis. The rate of hazard for each variable and 95\% confidence interval were calculated. The results for $\mathrm{p}<0.05$ were accepted as statistically significant.

\section{Results}

One hundred and forty hospitalized COPD patients with exacerbation in the ten-year period were examined in the study. It was found that 87 of them were alive, while 53 were dead. The etiology of deaths and the proportion of in-hospital or ex-hospital mortality were demonstrated in Figure 1. Thirty one patients $(58.5 \%)$ died due to COPD while 10 patients $(18.9 \%)$ died due to lung carcinoma. 


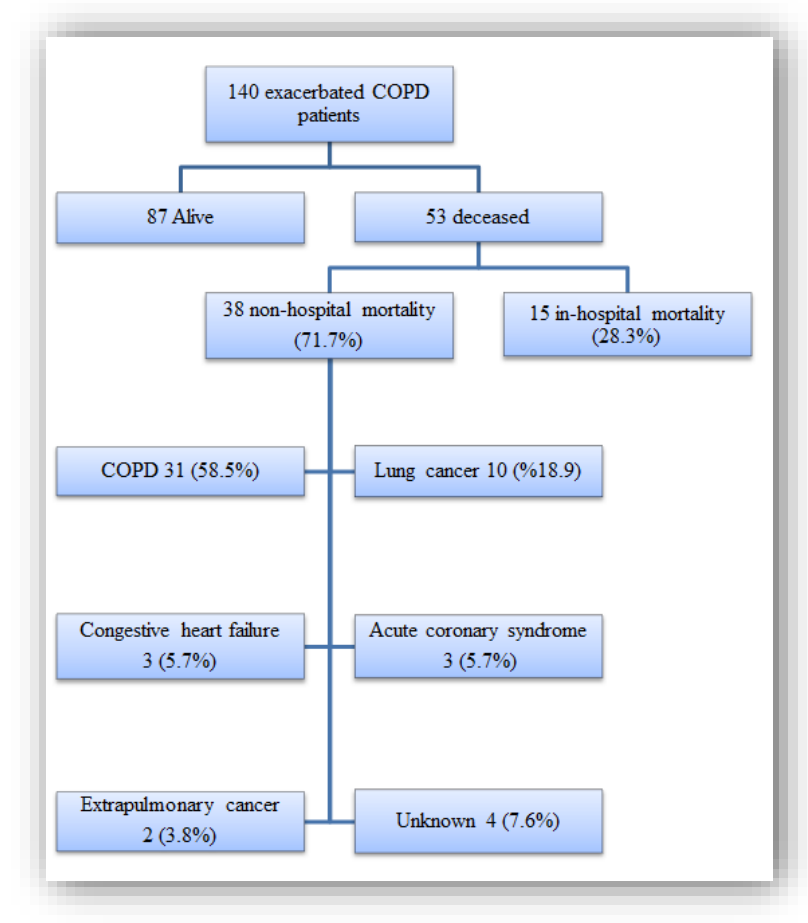

Figure 1. Distribution of death causes of 140 hospitalized COPD exacerbation patients.

CORD: Chronic obstructive pulmonary diseaze

Demographic data of both groups were deceased group, 11 (20.8\%) patients had CCI analyzed (Table 1). None of the parameters $\geq 7$. According to the univariate logistic had statistically significant effect on mortality regression analysis, the presence of lung with the univariate logistic regression analysis cancer and high CCI increases mortality 3.4 ( $p>0.05$ ). Data on PTFs at index admission, were available in $81(96.4 \%)$ of the alive patients and in $35(79.5 \%)$ of the deceased patients. There was no statistically significant difference between the groups $(\mathrm{p}>0.05)$.

Comorbities were shown in Table 2. None of and 4.4 times higher, respectively $(p<0.001)$. The COTE index was significantly higher in deceased patients $(p<0.001)$. The univariate analysis showed that high COTE score increases mortality 1.1 times higher $(p=0.012)$. the alive patients had $\mathrm{CCI} \geq 7$. However, in

Table 1. Demographic features of patients.

\begin{tabular}{lcccc}
\hline Variable & $\begin{array}{c}\text { Alive } \\
(\mathbf{n = 8 7})\end{array}$ & $\begin{array}{c}\text { Deceased } \\
(\mathbf{n = 5 3 )}\end{array}$ & $\mathbf{p}$ & $\begin{array}{c}\text { OR } \\
(\mathbf{9 5} \% \mathbf{C I})\end{array}$ \\
Age (years) (Mean \pm SD) & $68.7 \pm 8.7$ & $71.2 \pm 9.4$ & 0.122 & $1.555(0.663-5.561)$ \\
Female n(\%) & $14(16.1)$ & $8(15.1)$ & - & $1.000^{\mathrm{a}}$ \\
Male n(\%) & $73(83.9)$ & $45(84.9)$ & 0.875 & $1.029(0.728-1.454)$ \\
$\mathbf{B M I}\left(\mathbf{k g} / \mathbf{m}^{2}\right)($ Mean \pm SD) & $25.8 \pm 6.2$ & $26.1 \pm 9.3$ & 0.833 & $0.211(0.936-2.498)$ \\
Smoking n(\%) & $73(84.8)$ & $48(90.5)$ & 0.337 & $0.585(0.196-1.746)$ \\
Cigarettes & $50(1-200)$ & $59(8-180)$ & 0.311 & $1.005(0.996-1.014)$ \\
pack/year $($ Median)(min-max) & & & & \\
Smoking status n(\%) & & & & $1.000^{\mathrm{a}}$ \\
Never smoker & $8(9.3)$ & $2(3.8)$ & - & $2.800(0.523-14.992)$ \\
Active smoker & $19(21.8)$ & $8(15.1)$ & 0.229 & $2.776(0.550-14.004)$ \\
Ex-smoker & $51(58.6)$ & $36(67.9)$ & 0.216 & $2.333(0.310-17.545)$ \\
Passive smoker & $9(10.3)$ & $7(13.2)$ & 0.410 & \\
mMRC (Median)(min-max) & $4(1-12)$ & $4(2-4)$ & &
\end{tabular}

OR: Odds Ratio, CI: Confidence Interval, BMI: Body Mass Index, mMRC: modified Medical Research Council

a Reference category

Odds ratios were calculated by univariate logistic regression analyses. 
Table 2. Comorbidities in patients

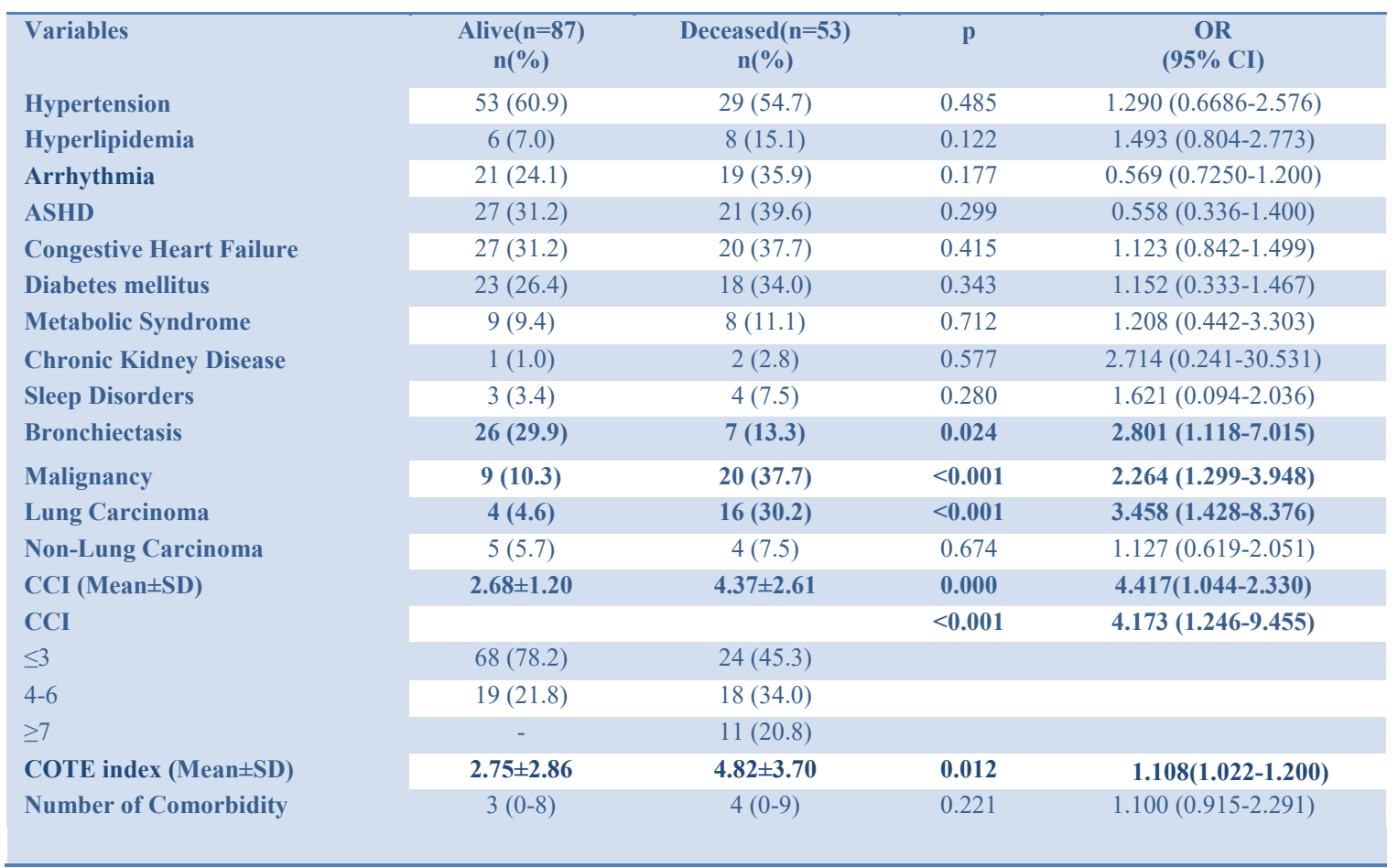

OR: Odds Ratio, CI: Confidence Interval, ASHD: Atherosclerotic heart disease. CCI: Charlson comorbidity index, COTE: COPD comorbidity index.

Odds ratios were calculated by univariate logistic regression analyses.

In stable condition $30.6 \%$ of the alive patients and $56 \%$ of the deceased patients were noncompliant to the inhaler medication. According to the univariate logistic regression analysis, noncompliance to medication and the use of short-acting anticholinergic was related with higher mortality $(p<0.001)$. There were no effects of the comorbidity treatment drugs on mortality.

LTOT was prescribed for $47(54.0 \%)$ of the alive patients and for $31(58.5 \%)$ of the deceased ones. Home NIMW treatment was prescribed $12(13.8 \%)$ of the alive patients and to $12(22.6 \%)$ of the deceased ones. NIMW did not have a statistically significant effect on mortality $(p>0.05)$. Irregular use of LTOT was related with higher mortality $(p<0.05)$.

The median number of exacerbations in the previous year was one in the alive group, while it was two in the group of deceased patients (Table 3). Eighteen point three percent of the alive patients were followed in intensive care unit and so were $39.6 \%$ of the deceased ones. The difference was statistically significant $(\mathrm{p}=0.013)$. Intubation was present in $6(6.9 \%)$ of the alive patients and in 12 $(22.7 \%)$ of the deceased ones. The difference was statistically significant $(\mathrm{p}=0.015)$.

Table 3. Exacerbation features of patients in previous year.

\begin{tabular}{lcccc}
\hline Variables & $\begin{array}{c}\text { Alive }(\mathbf{n}=\mathbf{8 7}) \\
\mathbf{n} \%\end{array}$ & $\begin{array}{c}\text { Deceased(n=53) } \\
\mathbf{n} \%\end{array}$ & $\mathbf{p}$ & $\begin{array}{c}\text { OR } \\
\mathbf{( 9 5 \%} \mathbf{C I})\end{array}$ \\
$\begin{array}{l}\text { Number of exacerbation } \\
\text { (Mean } \pm \text { SD) }\end{array}$ & $1.83 \pm 1.17$ & $1.83 \pm 0.99$ & 0.989 & $0.013(-0.380-0.348)$ \\
$\begin{array}{l}\text { Number of exacerbation } \\
\text { Median) (min-max) }\end{array}$ & $1(1-4)$ & $2(1-5)$ & 0.035 & $2.031(2.021-2.577)$ \\
$\begin{array}{l}\text { Patients who } \\
\text { requires ICU }\end{array}$ & $16(18.3)$ & $21(39.6)$ & 0.013 & $2.539(2.059-2.849)$ \\
$\begin{array}{l}\text { Patients who } \\
\text { requires intubation } \\
\text { Exacerbation Frequency }\end{array}$ & $6(6.9)$ & $12(22.7)$ & 0.015 & $2.485(2.035-2.515)$ \\
$\begin{array}{l}\text { One } \\
\geq 2\end{array}$ & $41(47.1)$ & $25(47.2)$ & - & $1.000^{\mathrm{a}}$ \\
\hline
\end{tabular}

OR: Odds Ratio, CI: Confidence Interval, ICU: Intensive care units,

a Reference category, Odds ratios were calculated by univariate logistic regression analyses 
Table 4 was contains the data about the exacerbation in index admission. While high C-reactive protein (CRP) $(\mathrm{p}=0.002)$, and erythrocyte sedimentation rate (ESR) $(\mathrm{p}=0.006)$ were risk factors, high $\mathrm{PaO} 2$ was protective for mortality $(\mathrm{p}=0.029)$. Intubation also increased the risk of mortality $(\mathrm{p}=0.020)$.
Table 5 contains the data about the ADO, modified ADO and DOSE indices for the index admission. High ADO index was a risk factor for increased mortality $(\mathrm{p}=0.026)$. Modified ADO index and DOSE index had no effect on mortality $(\mathrm{p}>0.05)$.

Table 4. Clinical features of exacerbation in index admission

\begin{tabular}{|c|c|c|c|c|}
\hline Variables & $\begin{array}{l}\text { Alive } \\
(\mathrm{n}=87)\end{array}$ & $\begin{array}{c}\text { Deceased } \\
(n=53)\end{array}$ & $\mathbf{p}$ & $\begin{array}{c}\text { OR } \\
(95 \% \mathrm{CI})\end{array}$ \\
\hline $\begin{array}{l}\text { ETBEH days } \\
\text { (Median) (min-max) }\end{array}$ & $10(2-60)$ & $10(1-30)$ & 0.012 & $0.951(0.810-0.993)$ \\
\hline $\begin{array}{l}\text { Length of hospitalization (Median) } \\
\text { (min-max) }\end{array}$ & $11(3-32)$ & $11(2-45)$ & 0.180 & $0.986(0.010-1.856)$ \\
\hline \multicolumn{5}{|l|}{ Exacerbation type n (\%) } \\
\hline Anthonisen Type 1 & $39(44.3)$ & $35(66.0)$ & 0.241 & $1.705(0.699-4.158)$ \\
\hline Anthonisen Type 2 & $30(34.1)$ & $8(15.1)$ & 0,223 & $0.507(0.170-1.511)$ \\
\hline Anthonisen Type 3 & $19(21.6)$ & $10(18.9)$ & - & $1.000^{\mathrm{a}}$ \\
\hline $\mathrm{PaO}_{2}(\mathrm{mmHg})(\mathrm{Mean} \pm \mathrm{SD})$ & $62.1 \pm 11.6$ & $57.2 \pm 16.6$ & 0.029 & $0.375(0.353-0.998)$ \\
\hline \multirow[t]{2}{*}{$\mathrm{PaCO}_{2}(\mathrm{mmHg})(\mathrm{Mean} \pm \mathrm{SD})$} & $41.9 \pm 11.5$ & $43.9 \pm 10.9$ & 0.317 & $1.017(0.975-1.050)$ \\
\hline & $(n=74)$ & $(n=42)$ & & \\
\hline \multirow[t]{2}{*}{ CRP (mg/L) (Mean \pm SD) } & $14.7 \pm 18.1$ & $35.0 \pm 42.6$ & 0.002 & $1.025(1.009-1.042)$ \\
\hline & $(n=74)$ & $(n=43)$ & & \\
\hline ESR $(m m /$ saat $)($ Mean \pm SD $)$ & $27.2 \pm 22.1$ & $42.9 \pm 35.5$ & 0.006 & $1.020(1.006-1.034)$ \\
\hline Intubated patients n (\%) & $6(6.9)$ & $12(22.7)$ & 0.020 & $1.201(1.018-1.214)$ \\
\hline
\end{tabular}

OR: Odds Ratio, CI: Confidence Interval, ETBEH: Elapsed time between exacerbation and hospitalisation, CRP: C-Reactive Protein, ESR: Erythrocyte sedimentation rate.

a Reference category

Odds ratios were calculated by univariate logistic regression analyses

Tablo 5. ADO, Modified ADO and DOSE indices distribution among the patients.

\begin{tabular}{|c|c|c|c|c|}
\hline Variables & $\begin{array}{c}\text { Alive }(n=84) \\
n \%\end{array}$ & $\begin{array}{c}\text { Deceased }(n=44) \\
n \%\end{array}$ & $\mathbf{p}$ & $\begin{array}{c}\text { OR } \\
(95 \% \mathrm{CI})\end{array}$ \\
\hline \multicolumn{5}{|l|}{ ADO index } \\
\hline $4-6$ & $44(75.9)$ & $14(24.1)$ & - & $1.000^{\mathrm{a}}$ \\
\hline$\geq 7$ & $40(57.1)$ & $30(42.9)$ & 0.026 & $1.328(1.034-1.704)$ \\
\hline \multicolumn{5}{|c|}{ Modified ADO index } \\
\hline$\leq 9$ & $30(68.2)$ & $14(31.8)$ & & $1.000^{\mathrm{a}}$ \\
\hline$\geq 10$ & $53(63.9)$ & $30(36.1)$ & 0.626 & $1.068(0.824-1.383)$ \\
\hline \multicolumn{5}{|c|}{ DOSE index } \\
\hline$\leq 3$ & $35(41.7)$ & $13(31.9)$ & - & $1.000^{\mathrm{a}}$ \\
\hline $4-6$ & $45(53.6)$ & $27(61.4)$ & 0.276 & $1.543(0.707-3.366)$ \\
\hline$\geq 7$ & $4(4.8)$ & $3(6.8)$ & 0.427 & $1.929(0.382-9.738)$ \\
\hline
\end{tabular}

OR: Odds Ratio, CI: Confidence Interval, ADO: Age, Dyspnea, Obstruction DOSE: Dyspnea, Obstruction, Smoking, Exacerbation

"Reference category

Odds ratios were calculated by univariate logistic regression analyses 
Multivariate Logistic Regression Analysis for Mortality

Multivariate logistic regression analysis showed that the patients developed lung cancer increased mortality independently by 2.58 times ( $\mathrm{p}=0.011$, CI [0.084-0.636]); $\mathrm{PaO} 2$ $<60 \mathrm{mmHg}$ increased mortality independently by 2.17 times $(p=0.031$, CI [0.001-0.012]); CCI $\geq 7$ increased mortality independently by 1.06 times $(p=0.041, C I$ [0.011-0.310]); and ICU admission more than 14 days increased mortality independently by 3.09 times $(\mathrm{p}=0.002$, CI [0.074-0.338]).

\section{Survival Analysis}

The mean period of follow-up in whole cohort was $79.3 \pm 69.9$ months. The lifespan of the survivors was $86.4 \pm 72.6$ months, while it was $67.6 \pm 64.2$ months in who did not survive. The death rate in the index admission was $2.5 \%$.
The 6 and 12-month mortality rate was $5 \%$. The 24 -month mortality was $12 \%$; the 60 month mortality was $28 \%$; and the 120 month mortality rate was $44 \%$.

\section{Kaplan Meier Analysis}

Kaplan Meier survival analysis results are demonstrated in Table 6. Age and sex did not affect the survival. Patients with COPD who develop lung cancer have two times shorter survival than those without lung cancer. COTE $\geq 4$ was associated with significantly decreased survival. The average survival with COPD of those who received a regular treatment and who had no criteria of respiratory insufficiency $(\mathrm{PaO} 2 \geq 60 \mathrm{mmHg})$ was statistically longer than the that of the patients who did not use a regular inhaler treatment and who had criteria of respiratory insufficiency $(\mathrm{p}=0.025, \mathrm{p}=0.024$, respectively) (Figure 2).

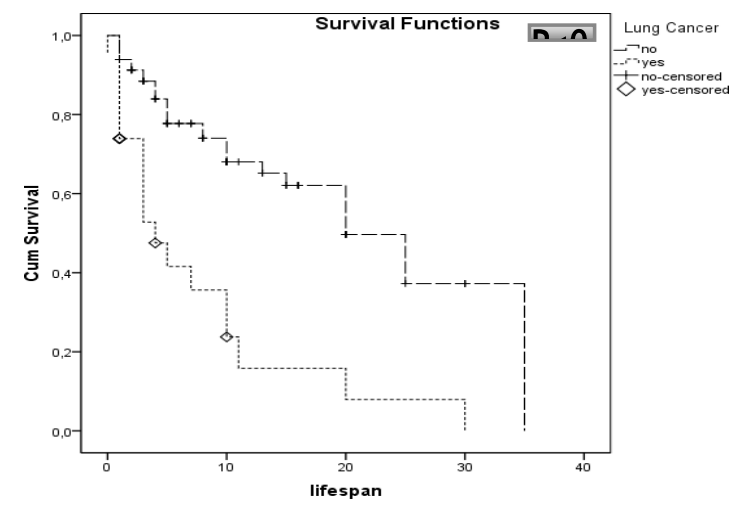

(A)+Lung cancer $(\mathbf{p}<\mathbf{0 . 0 0 1})$

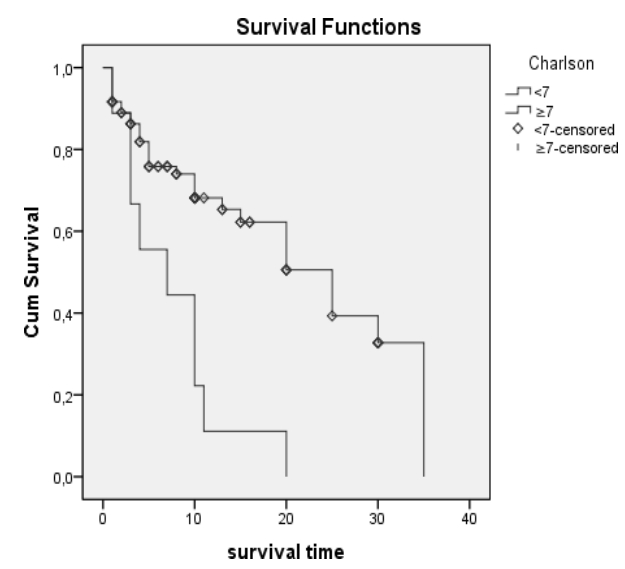


(B) Charlson Comorbidity Scores $(\mathrm{p}=\mathbf{0 . 0 0 1})$

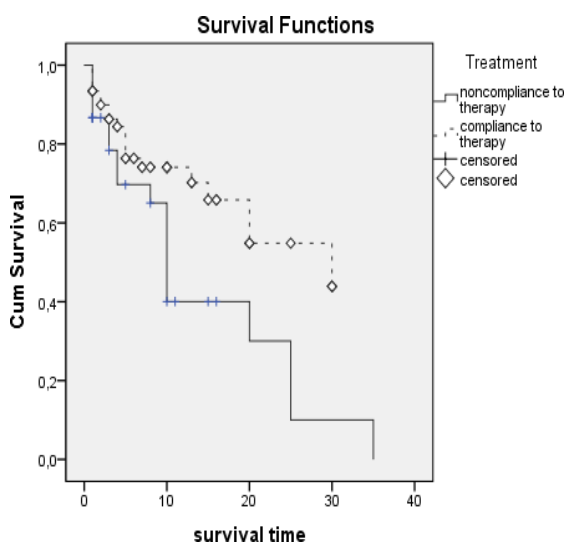

(C) Noncompliance to treatment $(p=0.025)$

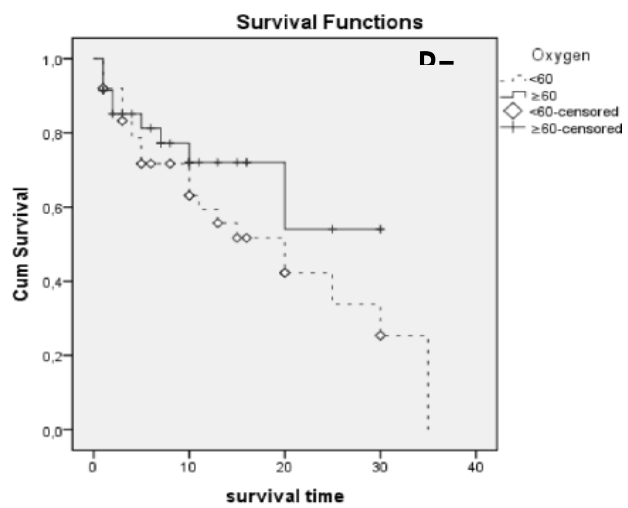

D) Low arterial partial oxygen level $(p=0.024)$

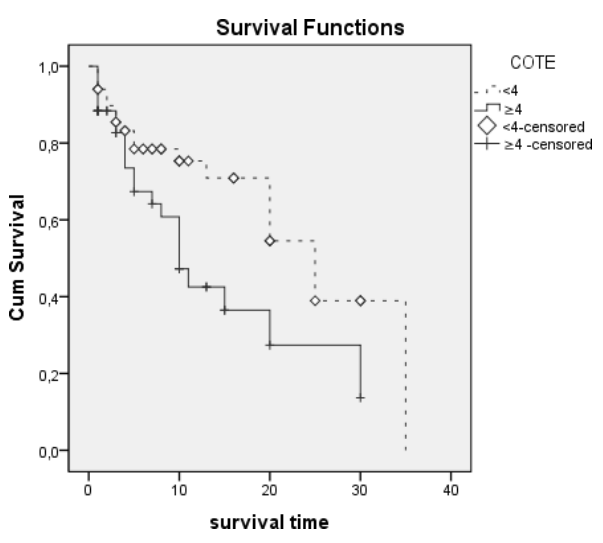

(E) COTE index $(p<0.001)$

Figure 2. Kaplan Meire Analysis showed (A) lung cancer $(p<0.001)$, (B) Charlson comorbidity index ( $p=0.001),(C)$ noncompliance to treatment $(p=0.025)$, (D) low arterial partial oxygen level $(p=0.024)$ and $(E)$ COTE $(p<0.001)$ were related with survival. 
Table 6. The life span of variables that are analyzed by univariate (Kaplan Meier)

\begin{tabular}{|c|c|c|c|}
\hline Variables & $\begin{array}{l}\text { Lifespan (month) } \\
\quad(\text { Mean } \pm \text { SD) }\end{array}$ & $\begin{array}{c}\text { Lifespan (month) } \\
\text { (Median) (min-max) }\end{array}$ & $\mathbf{p}$ \\
\hline \multicolumn{4}{|l|}{ Age group } \\
\hline$\leq 60$ years $(n=21)$ & $57.71 \pm 40.80$ & $60(0-132)$ & 0.124 \\
\hline$>60$ years $(n=119)$ & $83.19 \pm 73.38$ & $60(0-372)$ & \\
\hline \multicolumn{4}{|l|}{ Gender } \\
\hline Female $(n=22)$ & $98.72 \pm 83.05$ & $84(0-288)$ & 0.158 \\
\hline Male $(\mathrm{n}=118)$ & $75.76 \pm 67.03$ & $60(0-372)$ & \\
\hline \multicolumn{4}{|l|}{ Lung cancer } \\
\hline No $(n=120)$ & $86.0 \pm 72.6$ & $66(0-372)$ & $<0.001$ \\
\hline Yes $(n=20)$ & $39.6 \pm 29.1$ & $36(0-96)$ & \\
\hline \multicolumn{4}{|l|}{ CCI } \\
\hline $0-3(n=92)$ & $82.56+78.18$ & $48(0-372)$ & 0.192 \\
\hline $4-6 \quad(n=37)$ & $82.37+78.18$ & $48(0-324)$ & \\
\hline$\geq 7(n=11)$ & $42.54 \pm 27.02$ & $36(12-96)$ & \\
\hline \multicolumn{4}{|c|}{ Compliance to medication } \\
\hline $\begin{array}{l}\text { No }(n=54) \\
\text { Yes }(n=81)\end{array}$ & $\begin{array}{l}64.44+63.89 \\
92.14+72.93\end{array}$ & $\begin{array}{l}48(0-324) \\
72(0-372)\end{array}$ & 0.025 \\
\hline \multicolumn{4}{|l|}{$\mathrm{PaO}_{2}$} \\
\hline$<60 \mathrm{mmHg}(\mathrm{n}=68)$ & $82.76+71.19$ & $60(0-324)$ & \\
\hline \multicolumn{4}{|l|}{ CRP } \\
\hline $0-6 \mathrm{mg} / \mathrm{L}(\mathrm{n}=38)$ & $84.31 \pm 74.15$ & $60(0-252)$ & 0.666 \\
\hline$>6 \mathrm{mg} / \mathrm{L}(\mathrm{n}=65)$ & $78.27 \pm 64.76$ & $60(0-324)$ & \\
\hline \multicolumn{4}{|l|}{ ADO index } \\
\hline$\leq 6(n=58)$ & $73.03 \pm 63.54$ & $66(0-372)$ & 0.124 \\
\hline$\geq 7(n=70)$ & $92,05 \pm 75.61$ & $66(0-324)$ & \\
\hline \multicolumn{4}{|l|}{ COTE index } \\
\hline$<4(\mathrm{n}=50)$ & $11.22 \pm 9.25$ & $9(1-35)$ & 0.019 \\
\hline$\geq 4(n=43)$ & $7.84 \pm 7.29$ & $5(1-30)$ & \\
\hline
\end{tabular}

CCI: Charlson Comorbidity index, CRP: C-reactive protein, ADO: Age, Dyspnea, Obstruction Index, COTE: COPD comorbidity index

\section{Discussion}

In this retrospective cohort study in which an average 6.5-year-long term follow-up was conducted, the factors affecting the long- and short-term mortality after COPD exacerbation were analyzed with multiple statistical methods. While the six-month mortality was $5 \%$, the five-year mortality was $28 \%$. While the reason was COPD in $58.5 \%$ of the deaths, it was lung cancer in $18.9 \%$. The best predictor of mortality was lung cancer, while high CCI $(\geq 7)$ and COTE $(\geq 4)$ co-morbidity scores, non compliance to treatment, low $\mathrm{PaO} 2(<60 \mathrm{mmHg})$ value and long stay in ICU ( $\geq 14$ days) were among the other independent risk factors.

Hospitalization for severe exacerbations represents a major predictor of mortality (5).
Short-term mortality due to severe COPD exacerbation varied from $2.5 \%$ and $15 \%$ to $24 \%$ due to different settings. ICU admission remarkably increased the risk of mortality (20-22). Medium and long-term survival decreased after severe exacerbations. In Canada, a cohort study included 73,106 patients hospitalized for COPD exacerbation, showed a mortality rate of $50 \%$ and $75 \%$ at 3.6 and 7.7 years, respectively (23). The strongest mortality predictors were nonrespiratory organ system dysfunction and severity of the underlying respiratory function (22). Mortality reports from Turkey were scarce, revealing $17.8 \%$ in 5 years in outpatient setting and $39 \%$ in 3 years following exacerbations (24). 
The cause of death in COPD varied in severity of different diseases. In the mild-to-moderate diseases, cardiovascular reasons and the lung cancer are the leading cause of death; however, respiratory failure is the most common reason (25). The recent landmark studies showed that non-respiratory reasons of death are greater than respiratory reasons. The main non-respiratory reasons were cancer and cardiovascular diseases $(26,27)$. Our cohort consisted of severe COPD cases with severe exacerbation. The mean FEV1 was approximately $40 \%$, and the information about the etiology of mortality originated from verbal autopsy. Therefore, we did not exactly know whether the consideration of respiratory death in $58 \%$ of the patients was misclassified or not. The second most attributed reason was lung cancer, which was not surprising in that population. Lung cancer was the most powerful predictor of the mortality according to several statistical methods.

Several prognostic parameters such as age, sex, body mass index (BMI), smoking, functional status, comorbidities, exacerbations, respiratory physiology, and biomarkers were studied in stable and exacerbation settings. Some studies found that older age was a poor prognostic marker in exacerbation setting, while others were contrasting with these results $(8,13,16,19)$. Low BMI $(<20 \mathrm{~kg} / \mathrm{m} 2)$ and more specifically low fat free mass index were also found to be independently related with poor prognosis in large patient cohorts (15). In our study age, BMI, smoking, dyspnea levels, spirometric values and the number of the previous exacerbations were not associated with mortality; therefore, the multidimensional indices (ADO, modified ADO and DOSE) did not reveal any statistical significance. This may be best explained by the uniformity of patients' demography and the severity of the

\section{REFERENCES}

1. GBD 2015 Chronic Respiratory Disease Collaborators. Global, regional, and national deaths, prevalence, disability-adjusted life years, and years lived with disability for chronic obstructive pulmonary disease and asthma, 1990- disease described by FEV1 or dyspnea level in a single center setting.

Our study was composed of exacerbated patients and the major impacts in prognosis were the presence of lung carcinoma, low $\mathrm{PaO} 2$ in index admission, and the presence of previous ICU admission, high CCI and COTE scores and nonadherence to therapy. Although cardiovascular diseases were the most frequent comorbidities in the whole cohort, lung carcinoma was more frequent in decent patients (28). CCI was related with mortality in COPD patients (29). The mean CCI was 2 times more in decent patients in our cohort. The score $\geq 7$ was found to be associated with mortality in our cohort. More recently COTE was introduced as a COPD specific comorbidity score and was found to be related with increased mortality (9).

Although this study showed several remarkable issues, this was a retrospective and single center study with potential selection bias. The comorbidity evaluation and compliance to regular COPD treatment was based on self-reporting and patient records. The proactive approach was not applied for systematic evaluation. The mortality record was completed in the relatively small number of the entire cohort and related to the patient's called. This the limited factor for this research. Also, since the study is a retrospective study, there may be error in the assessment of infectious exacerbations and in determining the exacerbation severity.

In conclusion, the current results showed that the short and long term mortality in COPD was related with comorbidities in particular with lung carcinoma and respiratory insufficiency indicated by hypoxemia. Also, high CCI and COTE indices were a risk factor for increased mortality. 
for 20 age groups in 1990 and 2010: a systematic analysis for the Global Burden of Disease Study 2010. The Lancet. 2012; 380: 2095-128.

3. Cote CG. Surrogates of mortality in chronic obstructive pulmonary disease. Am J Med. 2006; 119(10): 54-62.

4. Celli BR. Predictors of mortality in COPD. Respir Med. 2010; 104: 773-9.

5. Soler-Cataluna JJ, Martinez-Garcia MA, Sanchez PR, et al. Severe acute exacerbations and mortality in patients with chronic obstructive pulmonary disease: Thorax 2005; 60: 925-31.

6. Vogelmeier CF, Criner GJ, Martinez FJ, et al. Global strategy for the diagnosis, management, and prevention of chronic obstructive lung disease 2017 report. GOLD executive summary. Am J Respir Crit Care Med. 2017; 195: 557-82.

7. Smith MC, Wrobel JP. Epidemiology and clinical impact of major comorbidities in patients with COPD. Int J Chron Obstruct Pulmon Dis. 2014; 9: 871.

8. Charlson ME, Pompei P, Ales KL, et al. A new method of classifying prognostic comorbidity in longitudinal studies: development and validation. J Chronic Dis. 1987; 40: 373-83.

9. Divo M, Cote C, de Torres JP, et al. Comorbidities and risk of mortality in patients with chronic obstructive pulmonary disease. Am J Respir Crit Care Med. 2012; 186: 155-61.

10. Celli BR, Cote CG, Marin JM, et al. The bodymass index, airflow obstruction, dyspnea, and exercise capacity index in chronic obstructive pulmonary disease. $N$ Engl $\mathrm{J} \mathrm{Med.} \mathrm{2004;} \mathrm{350:}$ 1005-12.

11. Almagro P, Soriano JB, Cabrera FJ, et al. Shortand medium-term prognosis in patients hospitalized for COPD exacerbation: the CODEX index. Chest. 2014; 145: 972-80.

12. Halpin DM, Criner GJ, Papi A, et al. Global Initiative for the Diagnosis, Management, and Prevention of Chronic Obstructive Lung Disease. The 2020 GOLD Science Committee Report on COVID-19 and Chronic Obstructive Pulmonary Disease. Am J Respir Crit Care Med. 2021; 203: 24-36.

13. Miller MR, Crapo R, Hankinson J, et al. General considerations for lung function testing. Eur Respir J. 2005; 26: 153-61.

14. Anthonisen NR, Manfreda J, Warren CP, et al. Antibiotic therapy in exacerbations of chronic obstructive pulmonary disease. Ann Intern Med. 1987; 106: 196-204.

15. Fletcher CM. Standardised questionnaire on respiratory symptoms: a statement prepared and approved by the MRC Committee on the Aetiology of Chronic Bronchitis (MRC breathlessness score). BMJ. 1960; 2: 1665.

16. van der Bruggen-Bogaarts BA, van der Bruggen $\mathrm{HM}$, van Waes PF, et al. Assessment of bronchiectasis: comparison of HRCT and spiral volumetric CT. J Comput Assist Tomogr. 1996; 20: 15-9.

17. Puhan MA, Garcia-Aymerich J, Frey M, et al. Expansion of the prognostic assessment of patients with chronic obstructive pulmonary disease: the updated BODE index and the ADO index. The Lancet. 2009; 374: 704-11.
18. Puhan MA, Hansel NN, Sobradillo P, et al. Largescale international validation of the ADO index in subjects with COPD: an individual subject data analysis of 10 cohorts. BMJ open. 2012; 2(6).

19. Jones RC, Donaldson GC, Chavannes NH, et al. Derivation and validation of a composite index of severity in chronic obstructive pulmonary disease: the DOSE Index. Am J Respir Crit Care Med. 2009; 180: 1189-95.

20. Patil SP, Krishnan JA, Lechtzin N, et al. Inhospital mortality following acute exacerbations of chronic obstructive pulmonary disease. Arch Intern Med. 2003; 163: 1180-6.

21. Afessa B, Morales IJ, Scanlon PD, et al. Prognostic factors, clinical course, and hospital outcome of patients with chronic obstructive pulmonary disease admitted to an intensive care unit for acute respiratory failure. Crit Care Med. 2002; 30: 1610-5.

22. Seneff MG, Wagner DP, Wagner RP, et al Hospital and 1-year survival of patients admitted to intensive care units with acute exacerbation of chronic obstructive pulmonary disease. JAMA. 1995; 274: 1852-7.

23. Suissa S, Dell'Aniello S, Ernst P. Long-term natural history of chronic obstructive pulmonary disease: severe exacerbations and mortality. Thorax. 2012; 67: 957-63.

24. Gunen H, Hacievliyagil SS, Kosar F, et al. Factors affecting survival of hospitalised patients with COPD. Eur Respir J. 2005; 26: 234-41.

25. Anthonisen NR, Skeans MA, Wise RA, et al. The effects of a smoking cessation intervention on 14.5-year mortality: a randomized clinical trial. Ann Intern Med. 2005; 142: 233-9.

26. McGarvey LP, John M, Anderson JA, et al. Ascertainment of cause-specific mortality in COPD: operations of the TORCH Clinical Endpoint Committee. Thorax. 2007; 62: 411-5.

27. McGarvey LP, Magder S, Burkhart D, et al. Cause-specific mortality adjudication in the UPLIFT ${ }^{\circledR}$ COPD trial: findings and recommendations. Respir Med. 2012; 106: 515-21.

28. Putcha N, Drummond MB, Wise RA, et al. Comorbidities and Chronic Obstructive Pulmonary Disease: Prevalence, Influence on Outcomes, and Management. Semin Respir Crit Care Med. 2015; 36: 575-91.

29. Prudente R, Franco EA, Mesquita CB, et al. Predictors of mortality in patients with COPD after 9 years. Int $J$ Chron Obstruct Pulmon Dis. 2018; 13: 3389. 